\title{
Occupational exposure to bioburden in Portuguese bakeries: an approach to sampling viable microbial load
}

\author{
Carla Viegas $^{1,2}$, Ana Monteiro ${ }^{1,3}$, Elisabete Carolino ${ }^{1}$, and Susana Viegas ${ }^{1,2}$ \\ Health \& Technology Research Centre, Escola Superior de Tecnologia da Saúde, Instituto Politécnico de Lisboa ${ }^{1}$, \\ Centro de Investigação em Saúde Pública, Universidade NOVA de Lisboa², Escola Nacional de Saúde Pública, \\ Universidade NOVA de Lisboa ${ }^{3}$, Lisbon, Portugal
}

[Received in February 2018; Similarity Check in February 2018; Accepted in June 2018]

\begin{abstract}
In bakeries, a number of operations such as mixing are associated with exposure to air-suspended flour dust and related bioburden. The aim of this study was to find the best active sampling approach to the assessment of occupational exposure to bioburden in Portuguese bakeries based on the data obtained with the use of specific impaction and impinger devices. We used impaction to collect fungal particles from $100 \mathrm{~L}$ air samples onto malt extract agar (MEA) supplemented with chloramphenicol ( $0.05 \%)$. For growing fungi we also used dichloran glycerol (DG18) agar-based media and for mesophilic bacteria we used tryptic soy agar (TSA) supplemented with nystatin $(0.2 \%)$. For Enterobacteriaceae we used violet red bile agar (VRBA). With impingers we also collected $300 \mathrm{~L}$ air samples at the $300 \mathrm{~L} / \mathrm{min}$ airflow rate, inoculated onto the same culture media. The two methods, impaction and impinger, showed statistically significant differences in the following counts: fungal on MEA ( $\mathrm{z}=-2.721, \mathrm{p}=0.007)$, fungal on DG18 $(\mathrm{z}=-4.830, \mathrm{p}=0.000)$, total bacteria $(\mathrm{z}=-5.435, \mathrm{p}=0.000)$, and Gram-negative coliforms $(\mathrm{z}=-3.716, \mathrm{p}=0.000)$. In all cases the impaction method detected significantly higher concentrations than the impinger method. Fungal and bacterial loads were higher in the production unit and lower in the shop. The fungal load obtained with impaction varied between 10 and $5140 \mathrm{CFU} \mathrm{m}^{-3}$, and total bacterial counts ranged between 10 and $4120 \mathrm{CFU} \mathrm{m}^{-3}$. This study has shown that the impaction method is the best active sampling approach to assessing viable bioburden in this specific occupational environment, but a multi-faceted approach to sampling and analyses combining methods and media enables a more refined risk characterisation and, consequently, better tailored risk control measures to reduce adverse health outcomes in workers.
\end{abstract}

KEY WORDS: bacteria; bioburden; fungi; impaction, impinger; malt extract agar; DG18 agar; tryptic soy agar; violet red bile agar

Exposure to bioaerosols and more specifically to the bioburden (microbial contaminants such as fungi and bacteria) is a critical occupational risk factor that requires deep understanding $(1,2)$. Some workplaces, such as agriculture, waste, fishery, forestry, mining, construction, and day care have already been associated with higher occupational exposure to biological hazards $(1,3)$. Some studies have reported higher prevalence of respiratory diseases and airway inflammation among workers in these sectors (4-7). Exposure to flour dust has been associated with asthma, conjunctivitis, rhinitis, and dermal reactions, while the so called baker's asthma has become one of the most severe and frequent expressions of occupational allergy (8).

Exposure to flour dust and related bioburden in bakeries mainly occurs during grinding, sifting, and mixing (8). When raw materials are mixed, profuse organic dust particles disseminate through the air and remain aerosolised for a long time before settling. Hence the high potential for

Correspondence to: Carla Viegas, Health \& Technology Research Center, Escola Superior de Tecnologia da Saúde, Instituto Politécnico de Lisboa, Lisboa, E-mail: carla.viegas@estesl.ipl.pt exposure to bioburden and metabolites such as endotoxins, volatile organic compounds, and mycotoxins (9).

Sampling for bioburden in occupational environments can provide valuable information needed to characterise the exposure conditions, evaluate potential hazards to health, and establish control measures (10). Sampling methods are several and each situation is unique and requires specific methodology $(3,11)$. Theoretically, the most suitable way to assess indoor bioburden exposure is based on active air sampling. However, short sample times entail considerable drawbacks due to known large spatial and temporal variations (12). Bioburden has mostly been collected with stationary samplers, where exposure to microorganisms is calculated as time-weighted average of the airborne concentration at different sampling sites (10). Personal air sampling, in turn, provides a more accurate estimation of worker's exposure in the occupational environment (10). Epidemiological data from personal sampling have shown exposure-response associations almost twice as often as studies using stationary sampling $(10,13)$. Because of this, data obtained from stationary sampling need to be interpreted by a well-trained industrial hygienist following a more refined exposure assessment 
protocol with different sampling approaches or even different analytical methods.

Active bioburden sampling relies on three methods: impaction and impingement for stationary sampling and filtration for personal sampling $(3,14)$. Impactors use solid media such as agar to collect bioburden by impaction (3, 15). The number of colonies can be quantified by visual inspection after incubation, resulting in a direct viable bioburden count in a specific volume of air sampled $(3,15)$. This method is the recommended by the American Conference of Governmental Industrial Hygienists (ACGIH) (16) and by the Health Canada (17). Impinger sampling involves particle collection into liquid media. Normally, air is drawn by suction through a narrow inlet tube into a small flask containing the collection medium. Once sampling is complete, aliquots of the collection liquid can be cultivated in growth media to count viable microorganisms, since sample volumes and sampling times can be defined in advance $(3,15)$.

Although we can now rely on more refined analytical tools based on next-generation sequencing (NGS) technologies for occupational exposure assessments (18), culture-based methods will remain crucial, since they provide information about the infection potential of the bioburden present (19) and allow comparison with the existing guidelines (20).

The aim of this study was to find and discuss the best active sampling approach to assessing bioburden occupational exposure in bakeries based on data collected from impaction and impinger devices.

\section{MATERIALS AND METHODS}

As part of a larger exploratory study which received financial support from the Portuguese Authority for Working Conditions this study took place between May 2016 and June 2017 and included 14 Portuguese bakeries in the Lisbon district. Eight bakeries belonged to a company which also baked for school canteens and vending machines. Five were integrated in supermarkets owned by one owner. One produced only fresh dough and belonged to the same supermarket owner (Table 1).

Most bakeries had three working areas: production, where kneading machines and ovens were located and where dough was shaped; raw material warehouse, where workers stored raw materials for dough; and the shop, where baked bread and pastry were sold. Sampling sites and sampling periods were determined based on the high amount of time spent by workers on those places or dislocation frequency during their occupational activity (Table 1).

\section{Bioburden sampling}

We took 59 indoor air samples (100 L of air) using an impaction method at a flow rate of $140 \mathrm{~L} \mathrm{~min}^{-1}$ (Millipore Air Tester, Millipore, Billerica, MA, USA), and the particles were collected onto agar plates according to the manufacturer's instructions. We also took one outdoor sample for each bakery for reference (control). All indoor samples were collected from workplaces occupied by one or two workers. Three culture media were used for better selectivity between fungal and bacterial populations: malt extract agar (MEA) (Frilabo, Maia, Portugal) supplemented with chloramphenicol $(0.05 \%)$ and dichloran glycerol (DG18) (Frilabo) agar for fungi, tryptic soy agar (TSA) (Frilabo) supplemented with nystatin $(0.2 \%)$ for mesophilic bacteria, and violet red bile agar (VRBA) (Frilabo) for the Enterobacteriaceae (e.g. Gram-negative coliforms).

We also collected 59 air samples (300 L) using a Coriolis $\mu$ impinger (Bertin Technologies, Montigny-leBretonneux, France) at the airflow rate of $300 \mathrm{~L} \mathrm{~min}^{-1}$. Samples were collected into vials with $10 \mathrm{~mL}$ sterile phosphate-buffered saline ( $\mathrm{pH} 7.4$ ) with $0.05 \%$ Triton X. From each vial $150 \mu \mathrm{L}$ of the collection liquid was inoculated onto four culture media: $2 \%$ MEA with $0.05 \mathrm{~g} \mathrm{~L}^{-1}$ chloramphenicol media, DG18 agar, TSA with $0.2 \%$ nystatin, and VRBA.

All samples were incubated at $27^{\circ} \mathrm{C}$ for 5-7 days (fungi) or at $30^{\circ} \mathrm{C}$ and $35^{\circ} \mathrm{C}$ for 7 days (mesophilic bacteria and Gram-negative coliforms, respectively). After laboratory processing and incubation, the fungi and bacteria were counted and the counts expressed as colony-forming units

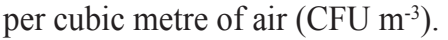

\section{Statistical analysis}

The data were analysed with the SPSS statistical software for Windows, v. 24.0 (IBM, Lisbon, Portugal). The threshold of significance was set at $5 \%(\mathrm{p}<0.05)$.

Table 1 Number of sampling sites in each bakery

\begin{tabular}{|c|c|c|c|}
\hline \multicolumn{2}{|c|}{ Bakeries } & \multirow{2}{*}{$\begin{array}{c}\text { Indoor air } \\
\text { sampling } \\
\text { impaction } \\
\text { (n) } \\
3+\end{array}$} & \multirow{2}{*}{$\begin{array}{c}\text { Indoor air } \\
\text { sampling } \\
\text { impinger } \\
\text { (n) }\end{array}$} \\
\hline 1 & Company bakery 1 & & \\
\hline 2 & Company bakery 2 & 5 & 5 \\
\hline 3 & Company bakery 3 & $4+$ & $4+$ \\
\hline 4 & Company bakery 4 & 4 & 4 \\
\hline 5 & Company bakery 5 & 5 & $5+$ \\
\hline 6 & Company bakery 6 & $4+$ & 4 \\
\hline 7 & Company bakery 7 & $5+$ & $5+$ \\
\hline 8 & Company bakery 8 & 4 & $4+$ \\
\hline 9 & Supermarket bakery 1 & 4 & 4 \\
\hline 10 & Supermarket bakery 2 & 4 & $4+$ \\
\hline 11 & Supermarket bakery 3 & 4 & 4 \\
\hline 12 & Supermarket bakery 4 & 3 & 3 \\
\hline 13 & Supermarket bakery 5 & 4 & 4 \\
\hline 14 & Fresh dough unit & 6 & $6+$ \\
\hline \multicolumn{2}{|c|}{ Total } & 59 & 59 \\
\hline
\end{tabular}

+ Not all the four media were used 
Table 2 Fungal and bacterial loads by method

\begin{tabular}{lccccc} 
& $\begin{array}{c}\text { Minimum } \\
\left(\mathbf{C F U} \mathbf{~ m}^{-3}\right)\end{array}$ & $\begin{array}{c}\text { Maximum } \\
\left(\mathbf{C F U} \mathbf{~ m}^{-3}\right)\end{array}$ & $\begin{array}{c}\text { Median } \\
\left(\mathbf{C F U} \mathbf{~ m}^{-3}\right)\end{array}$ & $\begin{array}{c}\text { Interquartile Range 25-75 } \\
\left(\mathbf{C F U} \mathbf{~ m}^{-3}\right)\end{array}$ & $\begin{array}{c}\text { No load was } \\
\text { detected }\end{array}$ \\
\hline $\begin{array}{l}\text { Impaction Fungal Load } \\
\text { MEA }\end{array}$ & 10.0 & 5140.0 & 235.0 & $110.0-1210.0$ & 7 \\
\hline $\begin{array}{l}\text { Impinger Fungal Load } \\
\text { MEA }\end{array}$ & 3.0 & 2620.0 & 85.0 & $13.0-310.0$ & 18 \\
\hline $\begin{array}{l}\text { Impaction Fungal Load } \\
\text { DG18 }\end{array}$ & 3.0 & 10310.0 & 140.0 & $17.0-740.0$ & 33 \\
\hline $\begin{array}{l}\text { Impinger Fungal Load } \\
\text { DG18 }\end{array}$ & 3.0 & 1670.0 & 10.0 & $7.0-80.0$ & 1 \\
\hline $\begin{array}{l}\text { Impaction Total Bacteria } \\
\text { Load TSA }\end{array}$ & 10.0 & 4120.0 & 235.0 & $150.0-475.0$ & 20 \\
\hline $\begin{array}{l}\text { Impinger Total Bacteria } \\
\text { Load TSA }\end{array}$ & 3.0 & 5306.7 & 7.0 & $3.3-28.5$ & 53 \\
\hline $\begin{array}{l}\text { Impaction Gram- Bacte- } \\
\text { ria Load VRB }\end{array}$ & 4.0 & 50.0 & 10.0 & $10.0-10.0$ & 69 \\
\hline $\begin{array}{l}\text { Impinger Gram-Bacteria } \\
\text { Load VRB }\end{array}$ & 3.0 & 3.3 & 3.2 & $3.0-3.3$ & \\
\hline
\end{tabular}

Table 3 Comparison of the fungal and bacterial counts between the impaction and impinger method

\begin{tabular}{|c|c|c|c|c|c|c|}
\hline & & & \multicolumn{2}{|c|}{ Ranks } & \multicolumn{2}{|c|}{ Test statistics ${ }^{\mathrm{m}}$} \\
\hline & & $\mathbf{N}$ & Mean rank & Sum of ranks & $\mathbf{Z}$ & $\mathbf{p}$ \\
\hline \multirow{4}{*}{$\begin{array}{l}\text { Impinger fungal load MEA - } \\
\text { Impaction fungal load MEA }\end{array}$} & Negative ranks & $45^{\mathrm{a}}$ & 34.99 & 1574.50 & \multirow{4}{*}{$-2.721^{n}$} & \multirow{4}{*}{$0.007 *$} \\
\hline & Positive ranks & $22^{\mathrm{b}}$ & 31.98 & 703.50 & & \\
\hline & Ties & $1^{\mathrm{c}}$ & & & & \\
\hline & Total & 68 & & & & \\
\hline \multirow{4}{*}{$\begin{array}{l}\text { Impinger fungal load DG18 - } \\
\text { Impaction fungal load DG18 }\end{array}$} & Negative ranks & $47^{\mathrm{d}}$ & 33.43 & 1571.00 & \multirow{4}{*}{$-4.830^{n}$} & \multirow{4}{*}{$0.000 *$} \\
\hline & Positive ranks & $13^{\mathrm{e}}$ & 19.92 & 259.00 & & \\
\hline & Ties & $8^{\mathrm{f}}$ & & & & \\
\hline & Total & 68 & & & & \\
\hline \multirow{4}{*}{$\begin{array}{l}\text { Impinger total bacterial load - } \\
\text { Impaction total bacterial load }\end{array}$} & Negative ranks & $55^{\mathrm{g}}$ & 29.18 & 1605.00 & \multirow{4}{*}{$-5.435^{\mathrm{n}}$} & \multirow{4}{*}{$0.000^{*}$} \\
\hline & Positive ranks & $4^{\mathrm{h}}$ & 41.25 & 165.00 & & \\
\hline & Ties & $2^{\mathrm{i}}$ & & & & \\
\hline & Total & 61 & & & & \\
\hline \multirow{4}{*}{$\begin{array}{l}\text { Impinger Gram-negative } \\
\text { bacterial load - Impaction } \\
\text { Gram-negative bacterial load }\end{array}$} & Negative ranks & $17^{\mathrm{j}}$ & 13.00 & 221.00 & \multirow{4}{*}{$-3.716^{n}$} & \multirow{4}{*}{$0.000 *$} \\
\hline & Positive ranks & $4^{\mathrm{k}}$ & 2.50 & 10.00 & & \\
\hline & Ties & $49^{1}$ & & & & \\
\hline & Total & 70 & & & & \\
\hline
\end{tabular}

a-impinger fungal load MEA < impaction fungal load MEA

$b$ - impinger fungal load MEA>impaction fungal load MEA

$c$ - impinger fungal load MEA=impaction fungal load MEA

$d$ - impinger fungal load DG18<impaction fungal load DG18

$e$ - impinger fungal load DG18>impaction fungal load DG18

$f$-impinger fungal load DG18=impaction fungal load DG18

$g$-impinger total bacteria load<impaction total bacteria load

$h$ - impinger total bacteria load $>$ impaction total bacteria load

$i$ - impinger total bacteria load=impaction total bacteria load

$j$-impinger coliform load<impaction coliform load

$k$-impinger coliform load $>$ impaction coliform load

$l$ - impinger coliform load=impaction coliform load

$m$ - Wilcoxon signed ranks test

$n$-based on positive ranks

* statistically significant $(p<0.05)$ 
Normality of distribution was tested with the Shapiro-Wilk test, but as it did not show normal distribution, we used the Wilcoxon test to compare the impaction and impinger methods for assessing fungal and bacterial loads.

We also compared the sensitivity and specificity between the impinger and impaction method.

For the comparison of fungal and bacterial loads (obtained with both methods) between the work areas (production, warehouse, and shop) we used the KruskalWallis test.

\section{RESULTS}

Table 2 shows the fungal and bacterial loads by method. The two methods significantly differed in the following counts: fungal on MEA ( $\mathrm{z}=-2.721, \mathrm{p}=0.007)$, fungal on DG18 agar $(\mathrm{z}=-4.830, \mathrm{p}=0.000)$, total bacteria $(\mathrm{z}=-5.435$, $p=0.000)$, and Gram-negative coliforms $(z=-3.716$, $\mathrm{p}=0.000)$. In all of these cases, impaction yielded significantly higher counts than the impinger method (Table 3).

Table 4 compares the sensitivity and specificity of the impaction and impinger methods for fungal loads on MEA and DG18 and bacterial loads on TSA and VRB. The impinger method was more sensitive for fungal loads on MEA (70.49 \%) and on DG18 (53.33\%) and also for bacterial load on TSA $(72.13 \%)$. However, it was not nearly as specific $(0.00 \%, 15.15 \%$, and $5.56 \%$, respectively). In contrast, it was specific for Gram-negative coliforms $(74.24 \%)$ but not sensitive $(0.00 \%)$. The agreement between the two methods was also relatively low.

The three workplaces (production, warehouse, and the shop) did not significantly differ in either the fungal or bacterial load. However, the production area had almost consistently the highest fungal and bacterial loads (Figures 1 and 2).

\section{DISCUSSION}

Quite expectedly, the production area had the highest fungal and bacterial loads. Beside having more workers and raw materials out in the open $(21,22)$, this workplace has been reported for the highest particulate matter concentrations $(23,24)$, and particles are known bioburden carriers $(25,26)$.

However, the focus of this study was on the sampling methods. The impinger method is often used in occupational settings with higher microbial loads. Not only does this method allow dilution before incubation on plates but it also makes possible the use of molecular tools, as it produces liquid samples (3). This is not possible with samplers that employ impaction on solid media. On the downside, the impinger method yielded lower fungal counts than impaction, even though dry collection methods, such as impaction, usually report lower counts for stress-sensitive bioaerosols (27). The reason may be sought in liquid evaporation associated with longer operation with impingers, as it hampers fungal and bacterial viability (28).

Beside the sampling methods, the use of different fungal media (MEA and DG18 agar) allowed a more comprehensive insight into the problem, as it yielded different counts with the same sampling method, which has already been reported by others $(20,24)$. Yet both media showed good sensitivity to fungi, and the combination of the two media has been shown to give complementary information (29-31). As for the bacteria, TSA provides information about bacterial contamination and VRBA is more specific for the Gramnegative coliforms.

There are other factors, beside collection and media used, that can affect sampling, such as inlet efficiency, transmission efficiency, and collection efficiency $(2,10)$. Furthermore, the viable bioburden collected with both methods constitutes a small percentage of the total microbial

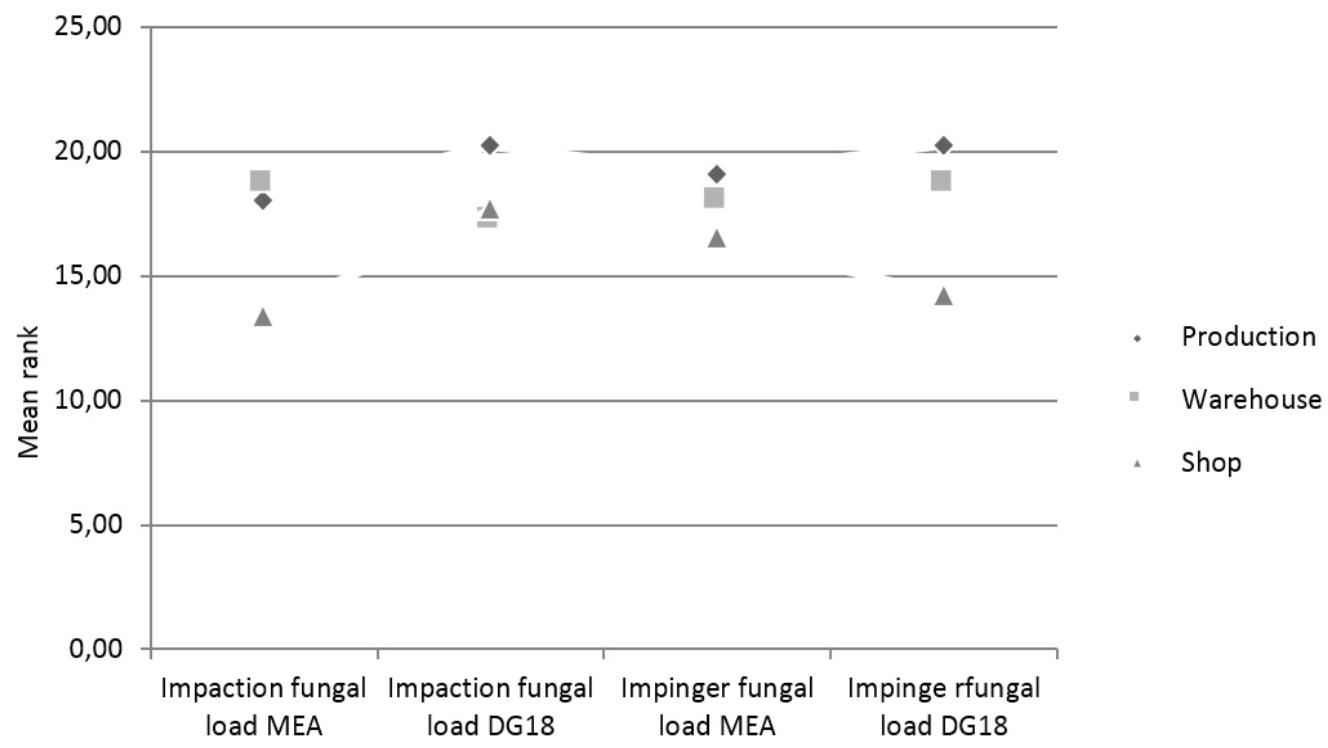

Figure 1 Mean ranks of the fungal loads across bakery units 


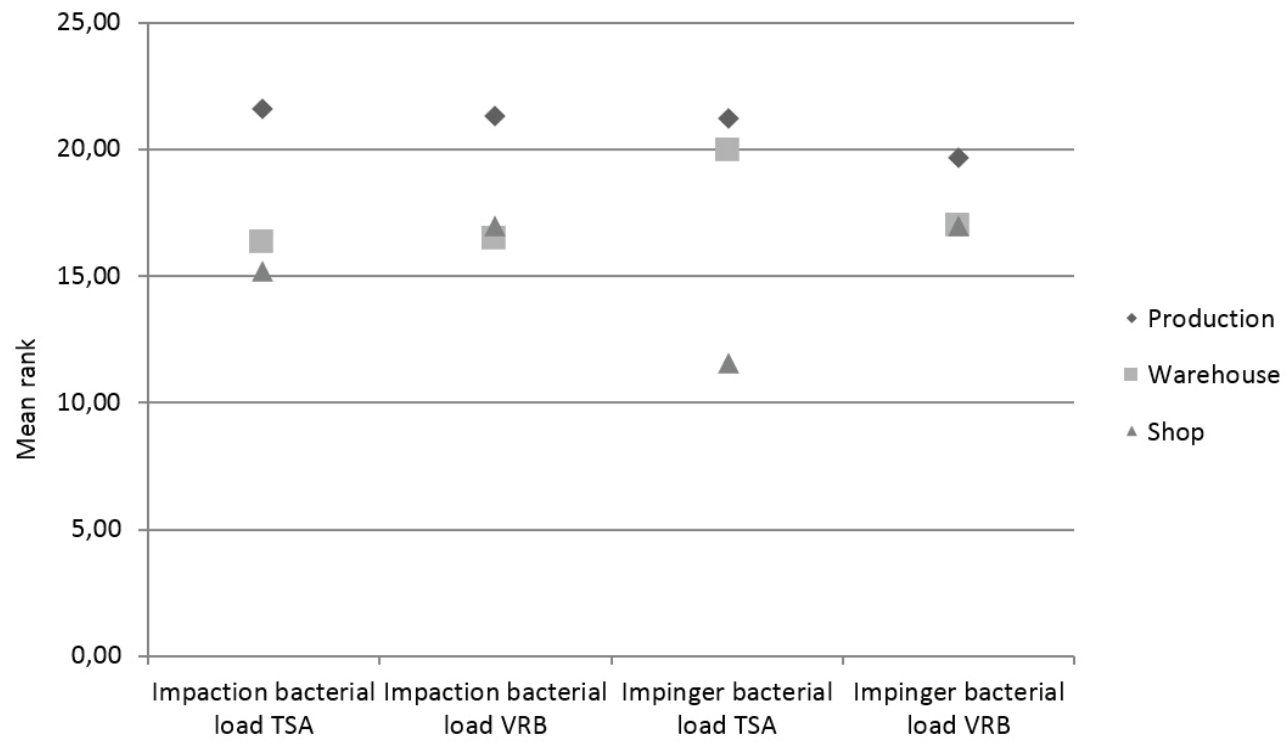

Figure 2 Mean ranks of bacterial loads across bakery units

Table 4 Sensitivity and specificity of the impinger and impaction method

\begin{tabular}{|c|c|c|c|c|c|c|c|}
\hline & \multicolumn{2}{|c|}{$\begin{array}{c}\text { Impinger fungal load } \\
\text { MEA }\end{array}$} & \multirow[t]{2}{*}{ Total } & \multirow[t]{2}{*}{ Sensitivity } & \multirow[t]{2}{*}{ Specificity } & \multirow{2}{*}{$\begin{array}{l}\text { Agreement between } \\
\text { the methods }(\%)\end{array}$} \\
\hline & & Not detected & Detected & & & & \\
\hline \multirow{2}{*}{$\begin{array}{l}\text { Impaction } \\
\text { fungal load } \\
\text { MEA }\end{array}$} & Not detected & 0 & 7 & 7 & \multirow{3}{*}{$70.49 \%$} & \multirow{3}{*}{$0.09 \%$} & \multirow{3}{*}{$63.24 \%$} \\
\hline & Detected & 18 & 43 & 61 & & & \\
\hline \multicolumn{2}{|c|}{ Total } & 18 & 50 & 68 & & & \\
\hline & & \multicolumn{2}{|c|}{$\begin{array}{c}\text { Impinger fungal load } \\
\text { DG18 }\end{array}$} & \multirow[t]{2}{*}{ Total } & \multirow{5}{*}{$53.33 \%$} & \multirow{5}{*}{$15.15 \%$} & \multirow{5}{*}{$54.41 \%$} \\
\hline & & Not detected & Detected & & & & \\
\hline \multirow{2}{*}{$\begin{array}{c}\text { Impaction } \\
\text { fungal load } \\
\text { DG18 }\end{array}$} & Not detected & 5 & 3 & 8 & & & \\
\hline & Detected & 28 & 32 & 60 & & & \\
\hline \multicolumn{2}{|c|}{$\begin{array}{c}\text { Total } \\
\end{array}$} & 33 & 35 & 68 & & & \\
\hline & & \multicolumn{2}{|c|}{$\begin{array}{c}\text { Impinger total bacterial } \\
\text { load }\end{array}$} & \multirow[t]{2}{*}{ Total } & \multirow{5}{*}{$72.13 \%$} & \multirow{5}{*}{$5.56 \%$} & \multirow{5}{*}{$72.58 \%$} \\
\hline & & Not detected & Detected & & & & \\
\hline \multirow{2}{*}{$\begin{array}{l}\text { Impaction } \\
\text { total bacte- } \\
\text { ria load }\end{array}$} & Not detected & 1 & 0 & 1 & & & \\
\hline & Detected & 17 & 44 & 61 & & & \\
\hline \multicolumn{2}{|c|}{ Total } & 18 & 44 & 62 & & & \\
\hline & & \multicolumn{2}{|c|}{$\begin{array}{l}\text { Impinger Gram-nega- } \\
\text { tive bacterial load }\end{array}$} & \multirow[t]{2}{*}{ Total } & \multirow{5}{*}{$0.00 \%$} & \multirow{5}{*}{$74.24 \%$} & \multirow{5}{*}{$70.04 \%$} \\
\hline & & Not detected & Detected & & & & \\
\hline \multirow{3}{*}{$\begin{array}{c}\text { Impaction } \\
\text { Gram-neg- } \\
\text { ative } \\
\text { bacterial } \\
\text { load } \\
\end{array}$} & Not detected & 49 & 4 & 53 & & & \\
\hline & Detected & 17 & 0 & 17 & & & \\
\hline & Total & 66 & 4 & 70 & & & \\
\hline
\end{tabular}


load (32) and this bias should be taken into consideration to properly interpret the obtained results $(2,20)$. The ability of a given airborne microbial population to grow on a medium is greatly affected by the physiological and physical stress caused by the aerosolisation, sampling methods, and other factors that affect airborne microbial cells $(33,34)$. Culture based-methods not only affect the microbial loads but also their biodiversity (35). In contrast, quantitative polymerase chain reaction (qPCR)-based methods can not differentiate between live and dead microorganisms, which is not totally suitable for infectious microorganisms and mainly occupational settings (36). Therefore, cultureindependent methods do not overcome all the limitations of the culture-based ones. While molecular tools such as next-generation sequencing (NGS) generally show greater biodiversity in aerosol samples than culture-based methods, more and more researchers recognise that culture-based and culture-independent methods are complementary $(20,36)$.

Given the complementarity of the culture basedmethods and molecular tools, we propose the following procedure: apply the impaction method to obtain information about the viable microbial load and the impinger method to target for specific microorganisms by later using molecular tools. This combination has already provided more comprehensive information about occupational exposure to bioburden $(31,37)$.

\section{CONCLUSIONS}

This study suggests that the impaction method is the best active sampling approach for occupational exposure assessment to viable bioburden in this specific occupational environment. Combining two or more fungal and/or bacterial media can provide even more information for exposure assessment. A multi-faceted approach to sampling and analyses is therefore welcome, as it enables a more refined risk characterisation and, consequently, better tailored risk control measures to reduce adverse health outcomes in workers.

\section{Acknowledgements}

The authors are grateful to the Portuguese Authority for Working Conditions for funding the Project "Occupational exposure assessment to particulate matter and fungi and health effects of workers from Portuguese Bakeries" (005DBB/12) and to the Fundação para Ciência e Tecnologia for funding the project EXPOsE - Establishing protocols to assess occupational exposure to microbiota in clinical settings (02/SAICT/2016 - Project no. 23222). Our thanks also go to the occupational health services of the bakeries participating in this study.

\section{Conflict of interest}

None.

\section{REFERENCES}

1. Wang CH, Chen BT, Han BC, Liu ACY, Hung PC, Chen CY, Chao HJ. Field evaluation of personal sampling methods for multiple bioaerosols. PLoS One 2015:10:e120308. doi: 10.1371/journal.pone.0120308

2. Reponen T. Sampling for microbial determinations. In: Viegas C, Viegas S, Quintal Gomes A, Taubel M, Sabino R, editors. Exposure to microbiological agents in indoor and occupational environments. Springer International Publishing 2017. p. 85-96. doi: 10.1007/978-3-319-61688-9_4

3. Viegas C, Pinheiro C, Sabino R, Viegas S, Brandão J Veríssimo C, editors. Environmental Mycology in Public Health: Fungi and Mycotoxins Risk Assessment and Management. $1^{\text {st }}$ ed. Academic Press 2015.

4. Heldal KK, Halstensen AS, Thorn J, Djupesland P, Wouters I, Eduard W, Halstensen TS. Upper airway inflammation in waste handlers exposed to bioaerosols. Occup Environ Med 2003;60:444-50. doi: 10.1136/oem.60.6.444

5. Bang B, Aasmoe L, Aamodt BH, Aardal L, Andorsen GS, Bolle R, Bøe R, Van Do T, Evans R, Florvåg E, Gram IT, Huser PO, Kramvik E, Løchen ML, Pedersen B, Rasmussen T. Exposure and airway effects of seafood industry workers in northern Norway. J Occup Environ Med 2005;47:482-92. doi: 10.1097/01.jom.0000161732.96555.2b

6. Heederik D, Sigsgaard T, Thorne PS, Kline JN, Avery R, Bønløkke JH, Chrischilles EA, Dosman JA, Duchaine C, Kirkhorn SR, Kulhankova K, Merchant JA. Health effects of airborne exposures from concentrated animal feeding operations. Environ Health Persp 2007;115:298-302. doi: 10.1289/ehp. 8835

7. Cox-Ganser JM, Rao CY, Park JH, Schumpert JC, Kreiss K. Asthma and respiratory symptoms in hospital workers related to dampness and biological contaminants. Indoor Air 2009;19:280-90. doi: 10.1111/j.1600-0668.2009.00586.x

8. Stobnicka A, Górny RL. Exposure to flour dust in the occupational environment. Int J Occup Saf Ergon 2015;21:241-9. doi: 10.1080/10803548.2015.1081764

9. Tsapko V, Chudnovets A, Sterenbogen M, Papach VV, Dutkiewicz J, Skórska C, Krysińska-Traczyk E, Golec M. Exposure to bioaerosols in the selected agricultural facilities of the Ukraine and Poland - a review. Ann Agric Environ Med 2011;18:19-27. PMID: 21736265

10. Reponen T, Willeke K, Grinshpun S, Nevalainen A. Biological particle sampling. In: Kulkarni P, Baron P, Willeke $\mathrm{K}$, editors. Aerosol measurement, principles, techniques, and applications. $3^{\text {rd }}$ ed. Hoboken (NJ): John Wiley \& Johns Inc.; 2011. p. 549-70.

11. Oppliger A. Advancing the science of bioaerosol exposure assessment. Ann Occup Hyg 2014;58:661-3. doi: 10.1093/ annhyg/meu04

12. Hyvärinen A, Vahteristo M, Meklin T, Jantunen M, Nevalainen A, Moschandreas D. Temporal and spatial variation of fungal concentrations in indoor air. Aerosol Sci Tech 2001;35:688-95. doi: 0.1080/02786820117763

13. Eduard W. The performance of culture-based methods and microscopy for quantification of noninfectious airborne microorganisms in epidemiological studies of highly contaminated work environments. AIHA J 2003;64:684-9. doi: $10.1080 / 15428110308984864$

14. Mandal J, Brandl H. Bioaerosols in indoor environment - a review with special reference to residential and occupational 
locations. Open Environ Biol Monit J 2011;4:83-96. doi: $10.2174 / 1875040001104010083$

15. Zollinger M, Krebs W, Brandl H. Bioaerosols formation during grape stemming and crushing. Sci Total Environ 2006;363:253-9. doi: 10.1016/j.scitotenv.2005.05.025

16. Verhoeff AP, Van Wijnen JH, Brunekreef B. Presence of viable mould propagules in indoor air in relation to house damp and outdoor air. Allergy 1992;47:83-91. doi: 10.1111/ j.1398-9995.1992.tb05093.x

17. Health Canada - Indoor Air Quality in Office Buildings: A Technical Guide. Vancouver, 1993 [displayed 10 July 2018]. Available at http://publications.gc.ca/collections/Collection/ H46-2-93-166Erev.pdf

18. Degois J, Clerc F, Simon X, Bontemps C, Leblond P, Duquenne P. First metagenomic survey of the microbial diversity in bioaerosols emitted in waste sorting plants. Ann Work Expos Heal 2017;61:1076-86. doi: 10.1093/annweh/ wxx075

19. Hung LL, Miller JD, Dillon KH, editors. Field Guide for the Determination of Biological Contaminants in Environmental Samples. $2^{\text {nd }}$ ed. Fairfax (VA): AIHA; 2005.

20. Viegas C, Faria T, Monteiro A, Aranha Caetano L, Carolino E, Quintal Gomes A, Viegas S. A novel multi-approach protocol for the characterization of occupational exposure to organic dust - swine production case study. Toxics 2018;6:5. doi: $10.3390 /$ toxics 6010005

21. Brown JS, Gordon T, Priceand O, Asgharian B. Thoracic and respirable particle definitions for human health risk assessment. Part Fibre Toxicol 2013;10:12. doi: 10.1186/17438977-10-12

22. Chmielowiec-Korzeniowska A, Tymczyna L, Drabik A, Krzosek L. Microbial contamination level of air in animal waste utilization plants. Ann Agric Environ Med 2016;23:548. doi: 10.5604/12321966.1196852

23. Viegas C, Monteiro A, Aranha Caetano L, Faria T, Carolino E, Viegas S. Electrostatic dust cloth: a passive screening method to assess occupational exposure to organic dust in bakeries. Atmosphere 2018;9:64. doi: 10.3390/atmos9020064

24. Caetano LA, Faria T, Batista AC, Viegas S, Viegas C. Assessment of occupational exposure to azole resistant fungi in 10 Portuguese bakeries. AIMS Microbiology 2017;3:96075. doi: 10.3934/microbiol.2017.4.960

25. Viegas C, Smajdova L, Faria T, Gomes AQ, Viegas S. Bioburden exposure in highly contaminated occupational environments. In: Viegas C, Viegas S, Gomes A, Täubel M, Sabino R, editors. Exposure to microbiological agents in indoor and occupational environments. Heidelberg: Springer; 2017. p. 335-59. doi: 10.1007/978-3-319-61688-9_17

26. De Nuntiis P, Maggi O, Mandrioli P, Ranalli G, Sorlini C. Monitoring the biological aerossol. In: Mandrioli P, Caneva G, Sabbioni C, editors. Cultural heritage and aerobiology methods and measurement techniques for biodeterioration monitoring. Dordrecht: Kluwer Academic Publishers; 2003. p. $107-44$

27. Dybwad M, Skoga G, Blatny JM. Comparative testing and evaluation of nine different air samplers: end-to-end sampling efficiencies as specific performance measurements for bioaerosol applications. Aerosol Sci Tech 2014;48:282-95. Doi: 10.1080/02786826.2013.871501

28. Bergwall C, Stehn B. Comparison of selective mycological agar media for the isolation and enumeration of xerophilic moulds and osmotolerant yeasts in granulated white sugar. Zuckerindustrie 2002;127:259-64.

29. Harper T, Bridgewater S, Brown L, Pow-Brown P, StewartJohnson A, Adesiyun AA. Bioaerosol sampling for airborne bacteria in a small animal veterinary teaching hospital. Infect Ecol Epidemiol 2013;3:1-7. doi: 10.3402/iee.v3i0.20376

30. Viegas C, Faria T, Aranha Caetano L, Carolino E, Quintal Gomes A, Viegas S. Aspergillus spp. prevalence in different Portuguese occupational environments: What is the real scenario in high load settings? J Occup Environ Hyg 2017;14:771-85. doi: 10.1080/15459624.2017.1334901

31. Huang PY, Shi ZY, Chen CH, Den W, Huang WM, Tsai JJ. Airborne and surface-bound microbial contamination in two intensive care units of a medical center in central Taiwan. Aerosol Air Qual Res 2013;13:1060-9. doi: 10.4209/ aaqr.2012.08.0217

32. Heidelberg JF, Shahamat M, Levin M, Rahman I, Stelma G, Grim C, Colwell RR. Effect of aerosolization on culturability and viability of gram-negative bacteria. Appl Environ Microbiol1997;63:3585-8. PMCID: PMC168664

33. Zhen H, Han T, Fennell DE, Mainelis G. Release of free DNA by membrane-impaired bacterial aerosols due to aerosolization and air sampling. Appl Environ Microbiol. 2013;79:7780-9. doi: 10.1128/AEM.02859-13

34. Schoenborn L, Yates PS, Grinton BE, Hugenholtz P, Janssen $\mathrm{PH}$. Liquid serial dilution is inferior to solid media for isolation of cultures representative of the phylum-level diversity of soil bacteria. Appl Environ Microbiol 2004;70:4363-6. doi: 10.1128/AEM.70.7.4363-4366.2004

35. Duquenne P. On the identification of culturable microorganisms for the assessment of biodiversity in bioaerosols. Ann Work Expo Health 2018;62:139-46. doi: 10.1093/annweh/wxx096

36. Viegas C, Faria T, dos Santos M, Carolino E, Quintal Gomes A, Sabino R, Viegas S. Fungal burden in waste industry: an occupational risk to be solved. Environ Monit Assess 2015;187:99. doi: 10.1007/s10661-015-4412-y

37. Viegas C, Quintal Gomes A, Faria T, Sabino R. Prevalence of Aspergillus fumigatus complex in waste sorting and incineration plants: an occupational threat. Int J Environ Waste Manag 2016;16:353-69. doi: 10.1504/ IJEWM.2015.074939 


\section{Pristup uzorkovanju mikroorganizama radi utvrđivanja profesionalnog biološkog opterećenja u portugalskim pekarama}

Mnoge su djelatnosti u pekarama povezane s izloženosti lebdećim česticama brašna i pripadajućim mikroorganizmima, poput miješanja tijesta. Cilj je ovog istraživanja bio pronaći najbolji način aktivnog uzorkovanja radi ocjene profesionalne izloženosti biološkom opterećenju u portugalskim pekarama na temelju podataka dobivenih primjenom specifičnih impaktora i impingera. Impaktorom smo prikupljali čestice mikroskopski sitnih gljiva iz 100-litarskog uzorka zraka na agar od sladnog ekstrakta (engl. malt extract agar, krat. MAE) kojem je dodan kloramfenikol (0,05\%). Za rast gljiva također smo rabili dikloran glicerol (DG18) medij, a za mezofilne bakterije triptični sojin agar (TSA) s nistatinom ( $0,2 \%)$. $\mathrm{Za}$ enterobakterije smo rabili ljubičasto-crveni žučni agar (engl. violet red bile agar, krat. VRBA). Impingerima smo također prikupljali uzorke zraka (300 L) uz protok od 300 L po minuti te ih cijepili na iste medije. Dvije su se metode, impakcijska i impingerska, statistički značajno razlikovale u sljedećim parametrima: u opterećenju gljivama na mediju $\operatorname{MEA}(\mathrm{z}=-2,721, \mathrm{p}=0,007)$, na mediju DG18 $(\mathrm{z}=-4,830, \mathrm{p}=0,000)$, ukupnom bakterijskom opterećenju $(\mathrm{z}=-5,435, \mathrm{p}=0,000)$ te $u$ opterećenju gram-negativnim koliformima $(z=-3,716, p=0,000)$. U svim je tim slučajevima impakcijska metoda dala značajno više koncentracije od impingerske. Opterećenje gljivama i bakterijama bilo je, sasvim očekivano, više u prostoriji za pripremu tijesta, a niže u prodavaonici. Opterećenje gljivama dobiveno impakcijom kretalo se u rasponu od 10 do $5140 \mathrm{CFU} \mathrm{m}^{-3}$, a bakterijama u rasponu od 10 do $4120 \mathrm{CFU} \mathrm{m}{ }^{-3}$. Ovo je istraživanje izdvojilo impakcijsku metodu kao najbolji pristup aktivnom prikupljanju uzoraka za ocjenu opterećenja živim mikroorganizmima za ovaj specifični radni okoliš, ali bi višestrani pristup uzorkovanju i analizi, koji bi objedinjavao više metoda i medija, omogućio finiju karakterizaciju rizika, a time i mjere kontrole rizika koje bi bile bolje prilagođene specifičnim potrebama radi smanjenja štetnih zdravstvenih ishoda u radnika.

KLJUČNE RIJEČI: bakterije; biološko opterećenje; DG18 agar; gljive; impakcija, impinger; ljubičasto-crveni žučni agar; sladni agar; triptični sojni agar 